\title{
Inflammatory pre-conditioning restricts the seeded induction of a-synuclein pathology in wild type mice
}

Emily J. Koller ${ }^{1,2}$, Mieu M. T. Brooks ${ }^{1,2,4}$, Todd E. Golde ${ }^{1,2,3}$, Benoit I. Giasson ${ }^{1,2,3^{*}}$ and Paramita Chakrabarty ${ }^{1,2,3^{*}}$

\begin{abstract}
Background: Cell-to-cell transmission of a-synuclein (aSyn) is hypothesized to play an important role in disease progression in synucleinopathies. This process involves cellular uptake of extracellular amyloidogenic aSyn seeds followed by seeding of endogenous aSyn. Though it is well known that aSyn is an immunogenic protein that can interact with immune receptors, the role of innate immunity in regulating induction of aSyn pathology in vivo is unknown. Herein, we explored whether altering innate immune activation affects induction of aSyn pathology in wild type mice.
\end{abstract}

Methods: We have previously demonstrated that recombinant adeno-associated virus (AAV) mediated expression of the inflammatory cytokine, Interleukin (IL)-6, in neonatal wild type mice brains leads to widespread immune activation in the brain without overt neurodegeneration. To investigate how IL-6 expression affects induction of aSyn pathology, we injected mouse wild type aSyn fibrils in the hippocampus of AAV-IL-6 expressing mice. Control mice received AAV containing an Empty vector (EV) construct. Two separate cohorts of AAV-IL-6 and AAV-EV mice were analyzed in this study: 4 months or 2 months following intrahippocampal aSyn seeding.

Results: Here, we show that IL-6 expression resulted in widespread gliosis and concurrently reduced aSyn inclusion pathology induced by a single intra-hippocampal injection of exogenous amyloidogenic aSyn. The reduction in aSyn inclusion pathology in IL-6 expressing mice was time-dependent. Suppression of aSyn pathology was accompanied by reductions in both argyrophilic and p62 immunoreactive inclusions.

Conclusions: Our data supports a beneficial role of inflammatory priming of the CNS in wild type mice challenged with exogenous aSyn. A likely mechanism is efficient astroglial scavenging of exogenous aSyn, at least early in the disease process, and in the absence of human aSyn transgene overexpression. Given evidence that a proinflammatory environment may restrict seeding of aSyn pathology, this can be used to design anti-aSyn immunobiotherapies by harnessing innate immune function.

Keywords: a-synuclein, Gliosis, IL-6, Inclusion pathology, Seeding

\section{Background}

Synucleinopathies are a group of neurodegenerative diseases characterized by the presence of intra-cytoplasmic amyloidogenic inclusions comprised of the protein $\alpha$-synuclein $(\alpha \operatorname{Syn})[1,2]$. In most of these disorders, such as Parkinson's disease (PD) or dementia with Lewy bodies (DLB), these $\alpha$ Syn inclusions are predominantly

\footnotetext{
* Correspondence: bgiasson@ufl.edu; pchakrabarty@ufl.edu 'Department of Neuroscience, University of Florida, Gainesville, Florida 32610, USA

Full list of author information is available at the end of the article
}

neuronal [2, 3]. The majority of pathological $\alpha$ Syn in these inclusions are phosphorylated at the serine 129 residue and this modification is generally used as a biological marker to monitor inclusion formation when combined with other histological assays [3, 4].

The aberrant aggregation of $\alpha$ Syn to form amyloidogenic inclusions is thought to follow a prion-like mechanism involving the molecular conversion of protein monomers from their predominantly unfolded structure to a $\beta$-pleated sheet that can then polymerize into amyloid (reviewed in [4]). As part of this prionoid 
mechanism, such conformationally altered forms of $\alpha$ Syn can readily aggregate and can subsequently be propagated between cells [5-12]. Consistent with this model, both intracerebral or peripheral injections of recombinant $\alpha$ Syn amyloid seeds result in robust induction of $\alpha$ Syn pathology in $\alpha$ Syn transgenic mice and to a lesser extent, in wild type mice [6, 7, 9, 13-15]. Modeling studies have further shown that both soluble and aggregated $\alpha$ Syn can be released and taken up by cells via various mechanisms [16-18], providing proof of concept that pathological $\alpha$ Syn shares prion-type transmission properties.

The observations that innate immune activation is an invariant finding in synucleinopathies and that $\alpha$ Syn, by itself, can directly interact with immune cells suggest that innate immunity can potentially modify how exogenous $\alpha$ Syn is able to influence the onset and progression of $\alpha$-synucleinopathy (reviewed in $[19,20]$ ). In mouse models of $\alpha$ Syn inclusion pathology induced by exogenous $\alpha$ Syn aggregates, a significant component of the $\alpha$ Syn pathology is retained in glial cells [7, 21]. Glial cytoplasmic inclusions (Papp-Lantos bodies) and tuftshaped astrocytes laden with aggregated $\alpha$ Syn have been reported in patients with synucleinopathies, such as PD, multiple system atrophy (MSA) and DLB [22-25] as well as in transgenic mouse models of $\alpha$-synucleinopathy [26-28]. Mechanistically, extracellular $\alpha$ Syn can directly activate microglia by interacting with microglial receptors including TLR2 and TLR4 [29-31]. CNS resident astrocytes as well as macrophages can endocytose $\alpha$ Syn via dynamin-related pathways $[16,17]$, suggesting that immune pathways can potentially have disease modifying effects in $\alpha$-synucleinopathies.

To investigate how innate immune activation alters seeded $\alpha$-synucleinopathy in wild type mice, we used an Interleukin (IL)- 6 driven somatic transgenesis model. IL-6 is a pleiotropic cytokine that plays a key role in immune regulation, hematopoiesis and acute phase reactions [32]. Under chronic conditions, IL-6 induces an acute inflammatory condition by activating immune cells, such as macrophages, B cells, microglia and astrocytes. Using recombinant adeno-associated viruses overexpressing IL-6 in the brains of wild type mice [33], we explored how preconditioning innate immune milieu in the CNS affects the induction of $\alpha$ Syn pathology following challenge with exogenous aggregated $\alpha$ Syn. IL- 6 expression, as expected, leads to widespread astrogliosis and, surprisingly, attenuates the induction of $\alpha$ Syn pathology in these mice. Thus, contrary to our expectations that an inflammatory milieu might exacerbate $\alpha$-synucleinopathy, we report that IL- 6 induced immune preconditioning limits induction of $\alpha$-synucleinopathy following injection of exogenous $\alpha \mathrm{Syn}$ aggregates.

\section{Methods \\ Mice}

All mouse husbandry and experimental procedures were conducted in accordance with IACUC and University of Florida policies. All mice were maintained under a $12 \mathrm{~h}$ light/dark cycle and had access to food and water ad libitum.

\section{Preparation of recombinant proteins and aSyn fibrils}

Recombinant full length mouse wild type $\alpha$ Syn was purified and fibrillized as described before [13, 34]. Briefly, recombinant $\alpha$ Syn was expressed and purified from $E$. coli, assembled in vitro into fibrils in PBS buffer and gently fragmented for 60 min using a bath sonicator before injection. Presence of endotoxins was assessed using the TLR4 assay (InvivoGen). The experiments were done using batches of fibrillar $\alpha$ Syn seeds validated by K114 fluorescence and their ability to induce $\alpha$ Syn pathology in HEK293 cells [35]. Following validation steps, these fibrils were aliquoted and stored at $-80{ }^{\circ} \mathrm{C}$ till use.

\section{rAAV delivery and hippocampal stereotactic injections} rAAV were prepared as described previously [33]. Wild type $\mathrm{B} 6 / \mathrm{C} 3 \mathrm{H}$ mice received bilateral, intraventricular injections of rAAV (capsid 1) expressing the inflammatory cytokine IL-6 or the empty vector plasmid containing no expression cassette (EV) on neonatal day P0 as described previously [33]. Mice were aged to 2 months and bilaterally injected (coordinates from Bregma: A/P -2.2, $\mathrm{L}+/-1.6, \mathrm{D} /$ $\mathrm{V}-1.2)$ with pre-fibrillized wild type mouse $\alpha$ Syn aggregates in the hippocampus according to Sacino et al [7]. Fibrils $(2 \mu \mathrm{L}$ of $1 \mathrm{mg} / \mathrm{ml}$ synuclein fibrils per hemisphere) were injected at a rate of $0.2 \mu \mathrm{L}$ per min. Control mice were injected with sterile PBS in the hippocampus. Mice used in various cohorts are shown in Table 1.

\section{Immunohistochemistry}

Mice were euthanized by intra-cardiac perfusion and brains were fixed in neutral buffered formalin. Paraffinembedded brain sections were assessed with the following antibodies: GFAP (Cell Signaling, 1:1000), Iba1 (Wako, 1:1000); pSer129/81A aSyn (1:3000; [13, 36]); EP1536Y (AbCam, 1:1000); p62 (Protein Tech; 1:1000), cd11b (AbCam; 1:250), MHCII (Novus; 1:50) and NeuN (Abcam; 1:500). For all antibodies except cd11b and MHCII, antigen retrieval was performed by steaming for $25 \mathrm{~min}$ in water. For cd11b and MHCII, antigen retrieval was done by steaming in Dako Target Retrieval Solution S1699 (modified citrate buffer, pH 6.1). Colorimetric slides were treated with ImmPress reagents (Vector Labs) and visualized with 3, 3'diaminobenzidine followed by hematoxylin counterstaining. Fluorimetric slides were visualized with Alexa Fluor conjugated secondary antibodies (Invitrogen) and counterstaining with 4, 
Table 1 Mice used in study

\begin{tabular}{|c|c|c|c|c|}
\hline rAAV1 injection (P0) & Hippocampal injection (2 mo) & Harvest age & $n$ & Used in \\
\hline Naive & N/A & $1.5 \mathrm{mo}$ & 4 & Fig. 1, Additional file 1: Figure S1 \\
\hline rAAV1-IL-6 & N/A & $1.5 \mathrm{mo}$ & 4 & Fig. 1, Additional file 1: Figure S1 \\
\hline rAAV1-EV & aSyn & $6 \mathrm{mo}$ & 4 & $\begin{array}{l}\text { Figs. 2, 3, } 4 \text { and 5, Additional file 2: Figure } \mathrm{S} 2 \text { and } \\
\text { Additional file 3: Figure S3 }\end{array}$ \\
\hline rAAV1-EV & PBS & $6 \mathrm{mo}$ & 5 & $\begin{array}{l}\text { Figs. 2, 3, } 4 \text { and 5, Additional file 2: Figure } S 2 \text {, } \\
\text { Additional file 3: Figure } S 3 \text { and Additional file 4: Figure } S 4\end{array}$ \\
\hline rAAV1-IL6 & aSyn & $6 \mathrm{mo}$ & 5 & $\begin{array}{l}\text { Figs. 2, 3, } 4 \text { and 5, Additional file 2: Figure } \$ 2 \text { and } \\
\text { Additional file 3: Figure S3 }\end{array}$ \\
\hline rAAV1-IL6 & PBS & $6 \mathrm{mo}$ & 3 & $\begin{array}{l}\text { Figs. 2, 3, } 4 \text { and 5, Additional file 2: Figure } S 2, \\
\text { Additional file 3: Figure } S 3 \text { and Additional file 4: Figure S4 }\end{array}$ \\
\hline rAAV1-EV & aSyn & $4 \mathrm{mo}$ & 5 & Fig. 6, Additional file 5: Figure S5 \\
\hline rAAV1-IL6 & aSyn & $4 \mathrm{mo}$ & 5 & Fig. 6, Additional file 5: Figure S5 \\
\hline
\end{tabular}

6-diamidino-2-phenylindole (DAPI; Southern Biotech). All colorimetric slides were scanned using the Aperio XT whole slide scanner while fluorescent slides were visualized using Olympus BX60 microscope with a color digital camera.

\section{Modified Campbell-Switzer silver staining}

This was performed based on the original protocol by Switzer [37]. Briefly, brain sections were placed in $2 \%$ ammonium hydroxide for 15 min followed by incubation in Silver-Pyridine-Carbonate solution in the dark with gentle stirring for $40 \mathrm{~min}$. Slides were treated consecutively in $1 \%$ citric acid and acetate buffer $(\mathrm{pH} 5.0)$ followed by immersion in the developer solution (sodium carbonate, ammonium nitrate, silver nitrate and formalin). Color development was stopped by transferring slides to acetate buffer and further incubation in sodium thiosulfate for $30 \mathrm{~s}$. Finally, slides were dehydrated in a series of alcohols and coverslips were applied.

\section{Quantification of gliosis and spatial depiction of pathology in brain maps}

Paraffin-embedded brain sections were stained with anti GFAP and anti Iba-1 antibodies, images captured by Aperio XT scanner and analyzed using the Positive Pixel Count algorithm in ImageScope (Aperio). At least three slides were used to calculate an averaged immunostaining burden quantity by a blinded experimenter.

CNS distribution of $\alpha$ Syn pathology was performed by a blinded experimenter by visually evaluating slides from each experiment ( 4 month or 2 month cohorts) in a single sitting on an Evos light microscope (ThermoFisher). A secondary reviewer also performed random spot-checks to establish colorimetric assessment. Presence of $\alpha$ Syn pathology is represented by red dots on a brain map to reflect the relative levels of pathology in a qualitative manner. To quantitatively assess absolute aggregate counts, the number of EP1536Y and p62 immunoreactive inclusions were counted from different samples corresponding to slides that were all cut at a given neuroanatomic location.

\section{Quantification of IL6 levels by ELISA and IL-6 immunostaining on brains}

Wild type $\mathrm{B} 6 / \mathrm{C} 3 \mathrm{H}$ mice received bilateral, intraventricular injections of rAAV-IL-6 on neonatal day P0 and were harvested at 1.5 months. Mice brains were divided sagitally; left hemisphere was snap frozen for biochemical determination of IL-6 levels and right hemisphere was fixed in formalin and paraffin embedded as coronal sections for IL-6 immunohistochemistry. The frozen hemibrains were extracted in RIPA buffer containing $1 \mathrm{x}$ Protease inhibitor cocktail (Roche, Indianapolis, IN) and used for biochemical determination of IL-6 protein levels using the Opti EIA mouse IL- 6 assay (BD Biosciences) as described earlier [33]. Colorimetric assays were analyzed using the SoftMax data acquisition software (Molecular Devices). For immunohistochemistry, paraffin embedded slides were stained with anti IL-6 antibody (AbCam, 1:200) following antigen retrieval by steaming in Dako Target Retrieval Solution S1699 (modified citrate buffer, $\mathrm{pH}$ 6.1). Colorimetric slides were treated with ImmPress reagents (Vector Labs) and visualized with 3, 3'diaminobenzidine followed by hematoxylin counterstaining.

\section{Statistics and image processing}

All statistics were performed using the GraphPad Prism software (GraphPad). Images were mounted using Adobe Photoshop CS4.

\section{Results}

IL-6 expression induces gliosis in the brains of naïve wild type mice and aSyn fibril injected wild type mice

To explore the effect of chronic immune activation in a model of $\alpha$ Syn seeding in wild type mice, neonatal B6/ $\mathrm{C} 3 \mathrm{H}$ pups were transduced by bilateral injection of 
a

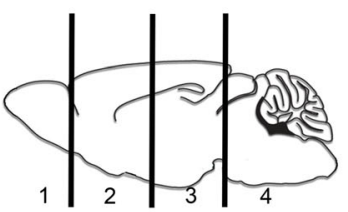

b

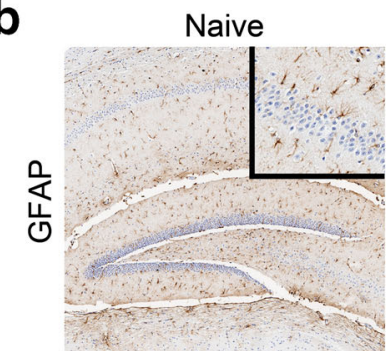

C

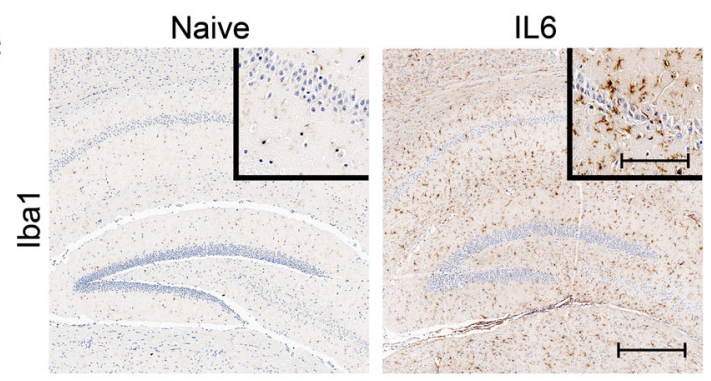

IL6

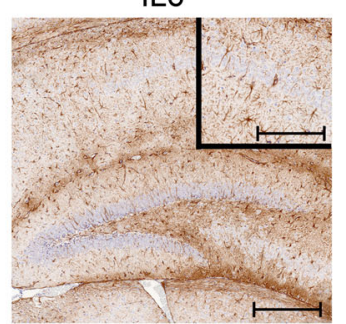

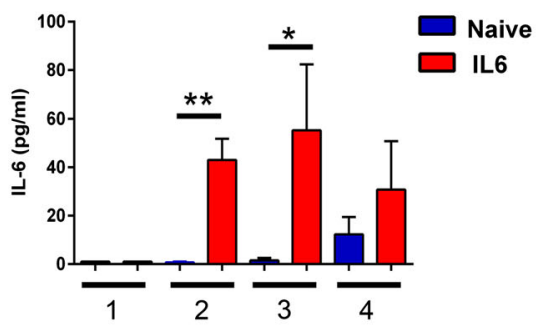

Naive
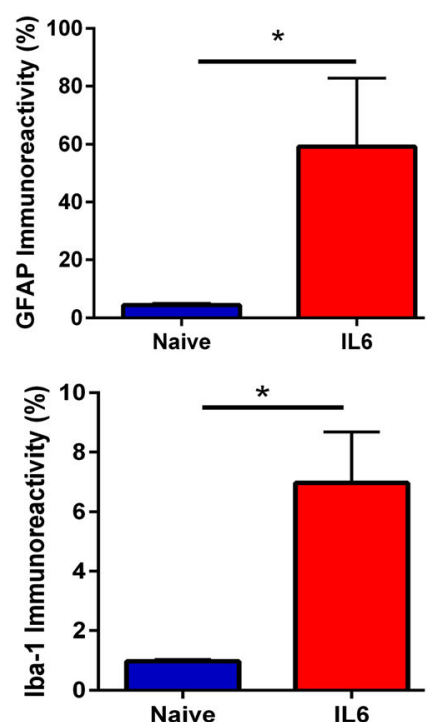

Fig. 1 Expression of IL-6 leads to widespread astrogliosis in the forebrain of wild type mice. Wild type mice were injected with rAAV-IL-6 on neonatal day P0 and analyzed at 1.5 months of age for IL-6 protein levels by ELISA (a). The numerals (on $x$ - axis) denote the different regions of a sagittally sectioned brain as shown on the model brain on the left panel (a). Uninjected (naïve) mice were used as controls. Mouse forebrains were also analyzed for astrocyte (GFAP) (b) and microglia (Iba-1) activation (c). GFAP and Iba-1 immunoreactivity was quantified and depicted across the whole forebrain $(\mathbf{b}-\mathbf{c}) . n=3$ mice/group. ${ }^{*} p<0.01,{ }^{*} p<0.05$, Student's $t$ test. Scale bar, $150 \mu \mathrm{m}$ and $40 \mu \mathrm{m}$ (inset)

rAAV1-Empty vector (rAAV1-EV) or rAAV1-IL-6 into the cerebral ventricles. $r A A V 1-E V$ injected animals were used as the control cohort in this study as these rAAV vectors contain the empty pAAV plasmid without any exogenous protein-encoding genes. Mice were aged to 1.5 months and analyzed for the extent of IL-6 expression and astrogliosis (Fig. 1). Direct ELISA determination of IL-6 levels showed that except for the anteriormost (olfactory bulb), IL-6 was upregulated by $\sim 40$ fold over control cohorts in forebrain and midbrain areas (Fig. 1a). Immunostaining for IL-6 protein revealed diffuse IL-6 reactivity in the neuropil as well as some cellular staining present throughout the forebrain and midbrain areas compared to control mice (Additional file 1: Figure S1). We also conducted detailed immunohistochemical analysis to assess GFAP immunoreactive astrocytes and Iba- 1 reactive microglia in the cortex and hippocampus. We observed widespread astrocytosis and microgliosis in IL-6 overexpressing mice (Fig. 1). Quantification of immunostaining using the positive pixel count program (Aperio ImageScope) showed significant increases in astrocytic staining ( $\uparrow 13.3 \mathrm{x}$ in IL-6 mice compared to naïve mice; Fig. $1 \mathrm{~b})$ and microglial staining $(\uparrow 7.1 \mathrm{x}$ in IL-6 mice compared to naïve mice; Fig. 1c) in IL-6 expressing mice compared to age-matched naïve mice.

Two month old mice transduced with rAAV1-IL-6 or rAAV1-EV were bilaterally injected with $2 \mu \mathrm{g}$ of wild type mouse $\alpha$ Syn fibrils or sterile saline (PBS) in the hippocampus. Mice were aged to 6 months of age and analyzed for astrogliosis in the hippocampal area. Four different groups were analyzed for astrogliosis: mice injected on neonatal day P0 with rAAV1-EV and subsequently injected in the hippocampus with either PBS or aggregated $\alpha$ Syn and mice injected on neonatal day P0 with rAAV1-IL-6 and subsequently injected in the hippocampus with either PBS or aggregated $\alpha$ Syn (Fig. 2, Additional file 2: Figure S2). Injection of $\alpha$ Syn fibrils in EV cohort induced astrogliosis compared to PBS injected mice (needle track, arrows, Fig. 2a), clearly showing that 


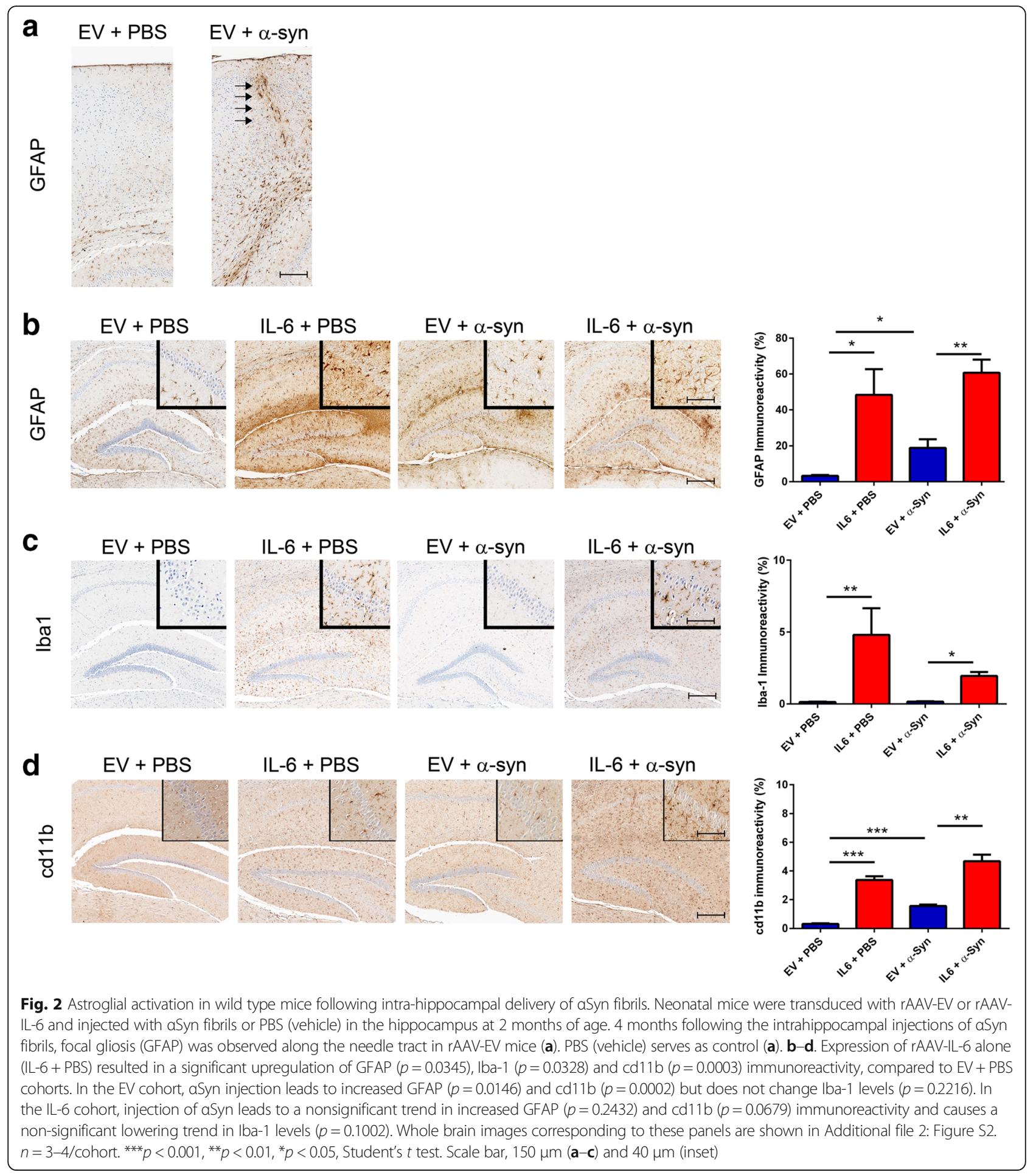

the presence of exogenous $\alpha$ Syn aggregates activated astrocytes at least focally. Overall, IL-6 + PBS mice show higher induction of astrocytosis (GFAP) and microgliosis (Iba-1 and cd11b) compared to EV + PBS mice (Fig. 2bd). Though injection of $\alpha$ Syn fibrils also increases cd11b and GFAP immunoreactivity in both IL-6 and EV cohorts (Fig. 2b, d), the extent of astrogliosis and microgliosis induced by $\alpha$ Syn fibrils (between $E V+P B S$ and $\mathrm{EV}+\alpha$ Syn cohorts) was considerably lower than the magnitude of glial activation observed in response to IL6 alone (between IL- 6 + PBS and EV + PBS cohorts) (Fig. 2b-d). Surprisingly, there was a non-significant 
lowering of Iba-1 immunoreactivity in IL-6 group compared to the EV groups following hippocampal delivery of aggregated $\alpha$ Syn (Fig. 2c). We also observed sparse MHCII immunopositive cells specifically around the ventricles in IL-6 alone or $\alpha$ Syn fibril injected cohorts (Additional file 3: Figure S3). MHCII staining was not observed in other areas of the brain, for example hippocampus or cortex (Additional file 3: Figure S3).

\section{IL-6 expression attenuates aSyn pathology following intrahippocampal injection of preformed aSyn fibrils} Injections of exogenous $\alpha$ Syn fibrils into predetermined areas of the mouse brain leads to $\alpha$ Syn inclusion pathology in wild type mice [13-15]. Here, we used a similar model of $\alpha$-synucleinopathy by injecting preformed mouse $\alpha$ Syn fibrils in the hippocampus of 2 month old wild type mice transduced with rAAV1-EV or rAAV1IL-6 on day P0. 4 months post injection, we detected $\alpha$ Syn pathology throughout the hippocampal CA1-3 and dentate gyrus and to a lesser extent in the sensorimotor cortex (Fig. 3a-c). No $\alpha$ Syn pathology was observed in other regions of the brain. The methodology used in our studies has been standardized in previous publications from our group [7, 13]; since we conducted bilateral seeding and used the whole brain for immunohistochemical assays that allow for accurate quantification, this precluded us from performing any biochemical assays of $\alpha$ Syn. Pathological $\alpha$ Syn was detected using two distinct antibodies raised against phosphorylated Ser129 epitope in $\alpha$ Syn: pSer129/81A [36] and EP1536Y (AbCam). We observed that in IL-6 expressing mice, the induction $\alpha$ Syn pathology was significantly lower in all the areas of the brain examined (Fig. 3a-c). The absolute counts of EP1536Y immunoreactive pSer129- $\alpha$ Syn inclusions in the whole brain showed that there was a $10.4 \mathrm{x}$ reduction in IL-6 expressing mice $(p=0.0023)$ (Fig. 3d). Using immunofluorescence colocalization in the hippocampus (Fig. 3e) and cortex (Fig. 3f), we confirmed that perikaryal pSer129/81A inclusions were mostly present in neurons (arrows, NeuN panel) in response to exogenous $\alpha$ Syn fibrils in EV cohorts. Intraneuronal $\alpha$ Syn inclusion staining was dramatically reduced in the hippocampus and cortex of IL-6 expressing mice compared to the EV cohort (Fig. 3e-f).

p62-reactive pathology induced by aSyn fibrils is attenuated in IL-6 expressing mice

The extent of $\alpha$ Syn pathology in EV or IL-6 expressing wild type mice was also confirmed with anti-p62/sequestosome antibody, which is a component of Lewy body inclusions $[38,39]$. Perikaryal and cytoplasmic p62 staining was localized in the cortex and hippocampus of EV injected mice, while IL- 6 expressing mice had considerably lower amounts of p62 stained inclusions in both areas (Fig. 4a, arrows). Overall, there was a 95\% decrease in p62-reactive cell body count in the hippocampus and cortex $(p<0.05)$ (Fig. 4b). We further confirmed that age-matched naïve mice (EV and IL-6 cohorts) which were not challenged with $\alpha$ Syn fibrils did not show accumulation of p62 inclusions (Additional file 4: Figure S4), confirming that the p62 induction is directly associated with the extent of pathological $\alpha$ Syn inclusions in these mice, and not with inflammatory activation.

IL-6 induced inflammatory milieu also limits the induction of argyrophilic inclusions by aSyn fibrils

Using Campbell-Switzer silver staining which detects Lewy body pathology [40], we examined the patterns of cytoplasmic inclusion pathology in EV and IL-6 cohorts following intrahippocampal delivery of $\alpha$ Syn fibrils. Consistent with patterns of pSer129 $\alpha$ Syn immunopositivity, we observed argyrophilic inclusions only in the brain regions contiguous to the injection site. In the EV cohorts, there was copious perikaryal staining mostly in the hippocampus and occasional staining was noted in the cortex. In the IL- 6 expressing mice, the intracellular silver staining was considerably lower in both the hippocampus and cortex (Fig. 5a-b).

\section{IL-6 induced attenuation of aSyn pathology is an early event}

To further investigate the timeline of the effect observed in IL-6 expressing mice, we assessed a second cohort of mice 2 months following intrahippocampal challenge with $\alpha$ Syn fibrils. Similar to earlier experiments, neonatal $\mathrm{B} 6 / \mathrm{C} 3 \mathrm{H}$ pups were transduced by bilateral injection of rAAV2/1-EV or rAAV2/1-IL-6 into the cerebral ventricles, aged to 2 months and then injected with $\alpha$ Syn fibrils in the hippocampus. When these mice were analyzed 2 months post injection, both GFAP and Iba-1 astrogliosis were upregulated in the forebrain areas in IL-6 expressing mice compared to EV cohorts (Additional file 5: Figure S5A-B). Examination of pSer129 $\alpha$ Syn immunopositivity in this cohort (2 months $\alpha$ Syn challenge) revealed a similar pattern that was observed in the first cohort ( 4 months $\alpha$ Syn challenge): IL-6 expressing mice had lower $\alpha$ Syn burden compared to EV cohorts when examined 2 months post $\alpha$-Syn challenge (Fig. 6a-d). The absolute counts of EP1536Y immunoreactive pSer129- $\alpha$-Syn inclusions in the whole brain showed that there was a $1.7 x$ reduction in IL- 6 expressing mice $(p=0.0251)$ (Fig. 6d). In IL-6 cohorts, $\alpha$ Syn immunopositivity was mostly restricted to the hippocampus whereas in the EV cohorts, perikaryal $\alpha$ Syn staining was observed in both hippocampus and cortex. There was a corresponding decrease in argyrophilic inclusions in the IL-6 injected mice compared to the EV injected mice (Fig. 6c). 


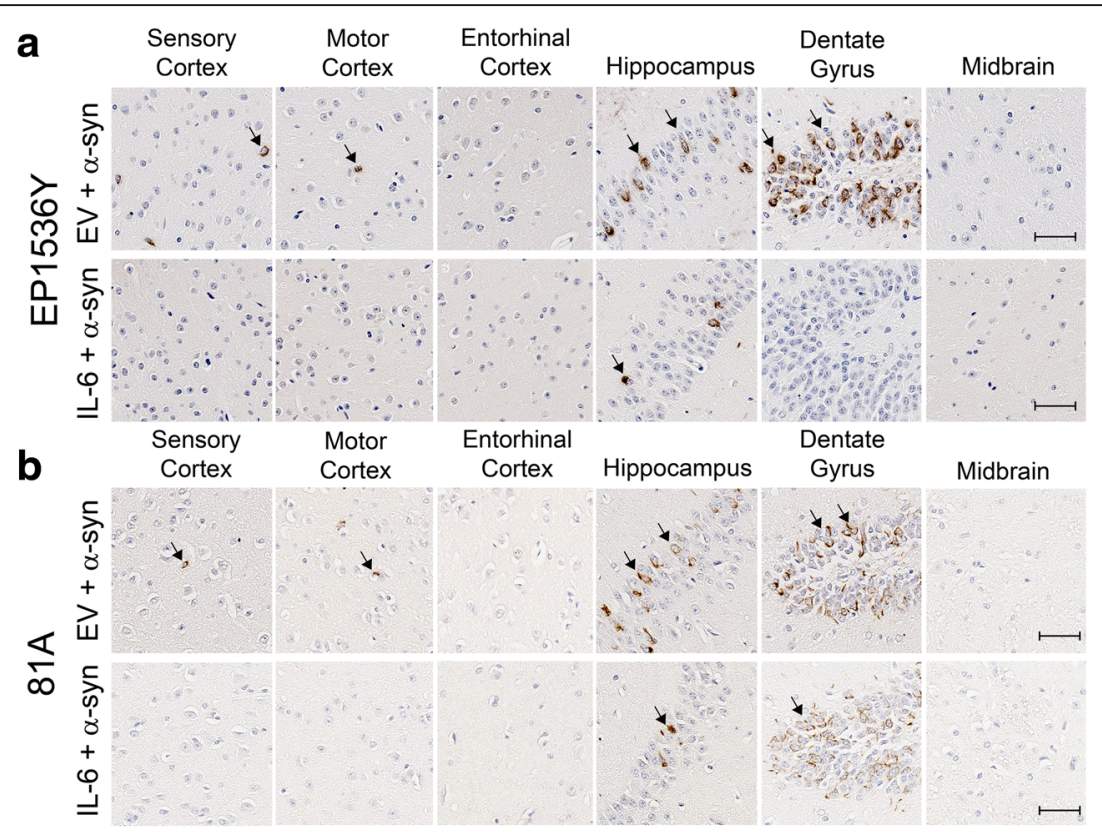

C
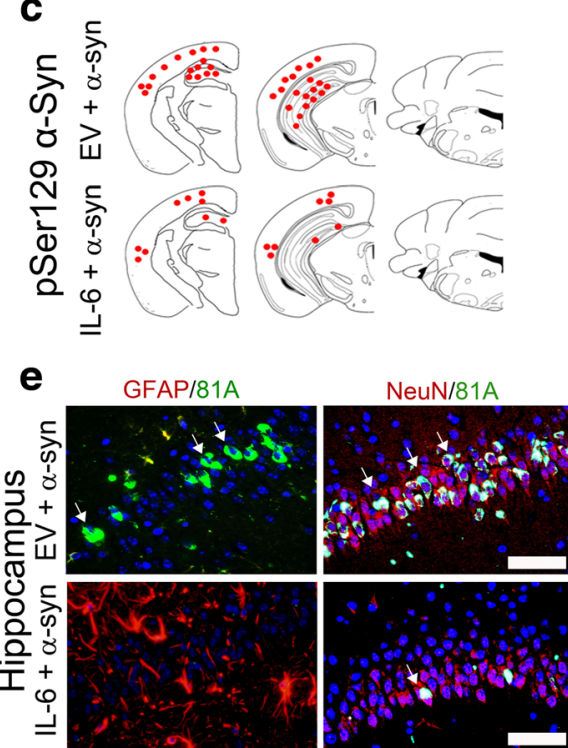

d
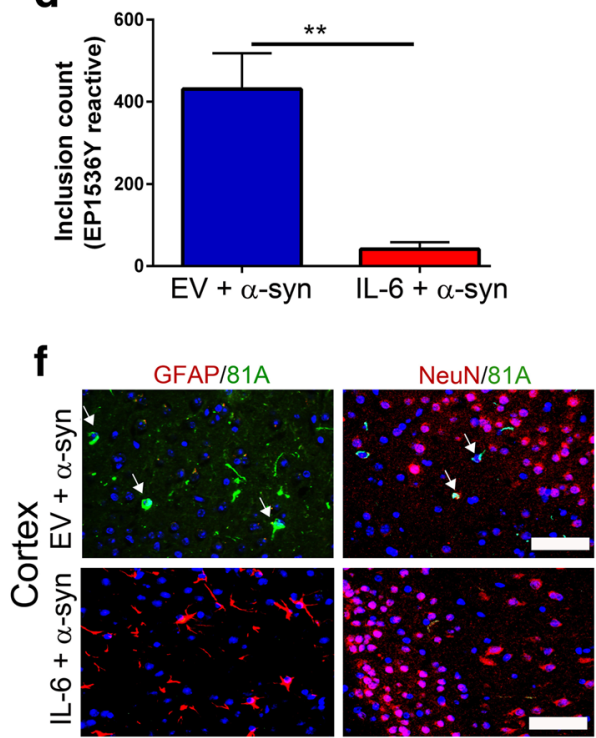

Fig. 3 IL-6 reduces aSyn pathology in wild type mice following intra-hippocampal injection of aSyn aggregates. Neonatal wild type mice were injected with rAAV-EV or rAAV-IL-6 and subsequently bilaterally injected in the hippocampus with aSyn fibrils at 2 months of age. Mice were analyzed 4 months post injection with aSyn fibrils in the hippocampus. Representative images of different brain regions stained with two antibodies (EP1536Y and $81 \mathrm{~A}$ ) that recognize the pSer129 epitope on aSyn are shown $(\mathbf{a}-\mathbf{b})$. The pattern and distribution of pSer129 aSyn pathology was similar with both antibodies. aSyn inclusions were mainly found in the hippocampus, dentate gyrus and cortical regions. Mice expressing IL-6 presented with lower levels of aSyn pathology than in EV control cohorts. Hematoxylin was used to counterstain tissues. Scale Bar, $25 \mu \mathrm{m}$. Red dots depicting rostral/caudal distribution of aSyn inclusions in wild type mice identified by pSer129 immunostaining is presented as a qualitative measure of relative amounts of aSyn burden (c). The actual number of aSyn inclusions were counted in EP1536Y stained sections (whole brain) of IL-6 and EV cohorts injected with aSyn aggregates $(\mathbf{d})$. ${ }^{*} p<0.01$. e-f, Co-immunofluorescence staining with GFAP (astrocyte marker, Alexa Fluor 594) or NeuN (neuronal marker, Alexa Fluor 594) with 81A antibody (Alexa Fluor 488) shows aSyn inclusions primarily localized in the neurons in the hippocampus (arrows, e) and cortex (arrows, f). Overall, intraneuronal aSyn inclusion pathology is reduced in IL-6 expressing mice. $n=4-5$ mice/cohort. Scale bar, $25 \mu \mathrm{m}$

\section{Discussion}

Here we have investigated the effect of inflammatory immune activation on the induction of $\alpha$ Syn pathology in wild type mice following intra-hippocampal delivery of pre-fibrillized $\alpha$ Syn aggregates. We show that expression of IL-6 in two independent time progressive cohorts of wild type mice results in 1) widespread and massive astrogliosis, 2) attenuation of induced $\alpha$ Syn 


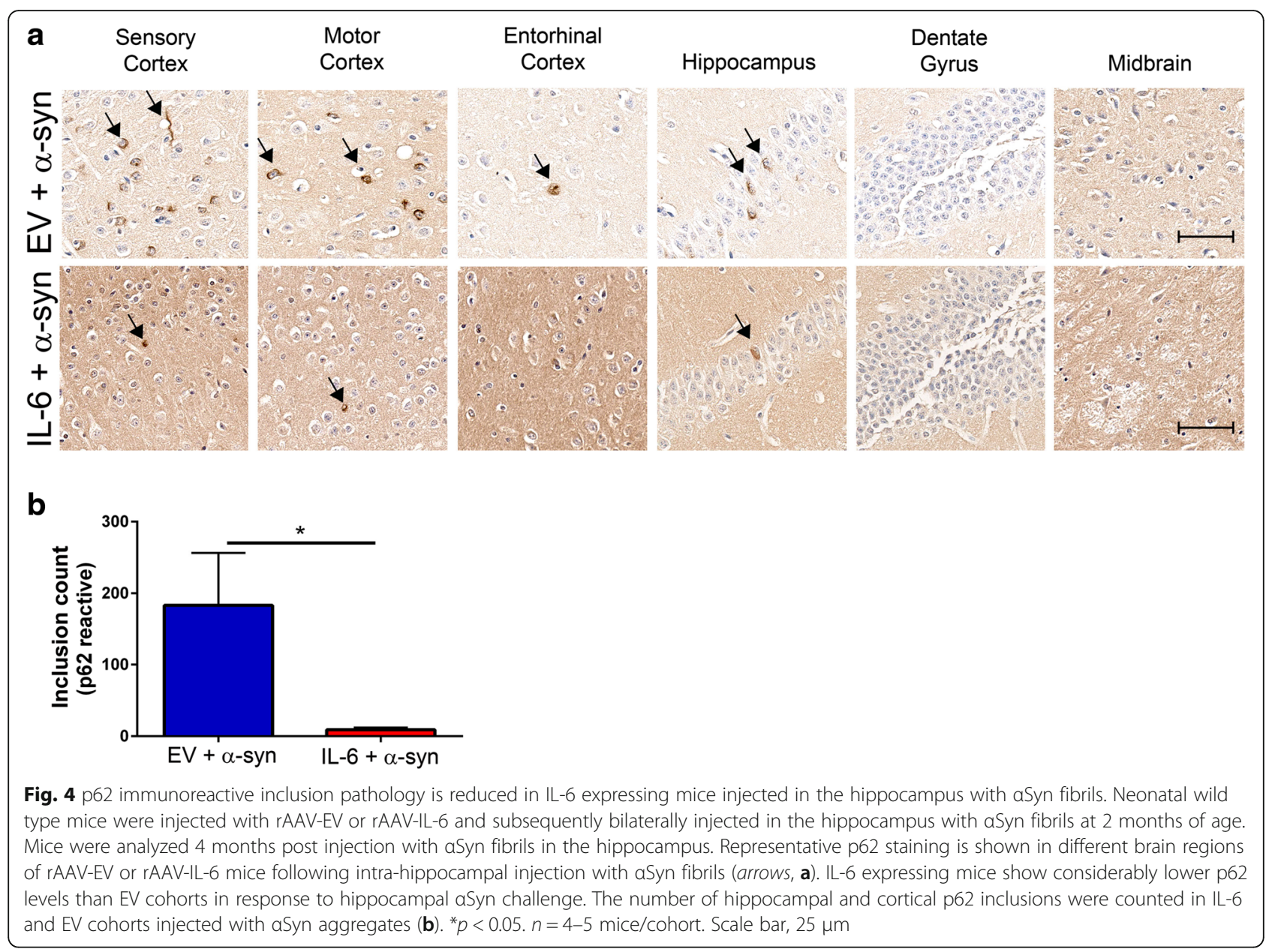

pathology in mice challenged with exogenous $\alpha$ Syn aggregates and 3) concurrent reduction in p62 and argyrophilic inclusion pathology in mice injected with $\alpha$ Syn. Our study is in agreement with earlier reports that $\alpha$ Syn can be readily endocytosed by astrocytes [16] and this is potentially an endogenous mechanism for rebalancing proteostasis abnormalities via lysosomal degradation [17]. Taken together, this suggests that prior activation of astroglia alters the innate immune milieu to generate a beneficial response in wild type mouse brains challenged with exogenous $\alpha$ Syn aggregates. However, whether IL-6 induced inflammatory activation will have a different outcome in a chronic setting, especially with regard to neurodegeneration and behavioral outcome measures, remains to be investigated.

Templated conformational alterations in intracellular $\alpha$ Syn and its subsequent secretion across neuroanatomic junctions has emerged as a possible mechanism of disease progression in $\alpha$-synucleinopathies [4]. However, little is known about the non-cell autonomous effects of extracellular $\alpha$ Syn on innate immunity in the CNS. More importantly, whether innate immune based strategies could potentially induce rapid uptake and degradation of extracellular $\alpha$ Syn in vivo by immune cells has not been studied. While chronic inflammation can have a detrimental role in CNS homeostasis [41], whether transient activation of astrocytes and microglia can be harnessed as a disease modifying therapy in $\alpha$ Syn models of PD is still unknown.

There are multiple reports showing that various therapies can attenuate $\alpha$ Syn pathology in transgenic mouse models (reviewed in [42]). However, only one previous report, using a peripherally administered monoclonal anti- $\alpha$ Syn antibody showed that prefibrillar $\alpha$ Syn aggregate induced $\alpha$-synucleinopathy can be blocked in vivo [43]. Additionally, the reported safety and preliminary efficacy of the ongoing AFFITOPE ${ }^{\circ}$ PD01A (AFFiRis AG) trials in human patients lends support to the idea that activating the patient's immune system to generate anti- $\alpha$ Syn response may be potentially beneficial in limiting the progression of $\alpha$ Syn pathology. Herein, we show that pro-inflammatory preconditioning significantly attenuates induction of endogenous $\alpha$ Syn pathology in wild type mice. Further, our data seems to suggest that in addition to potential immune scavenging of 


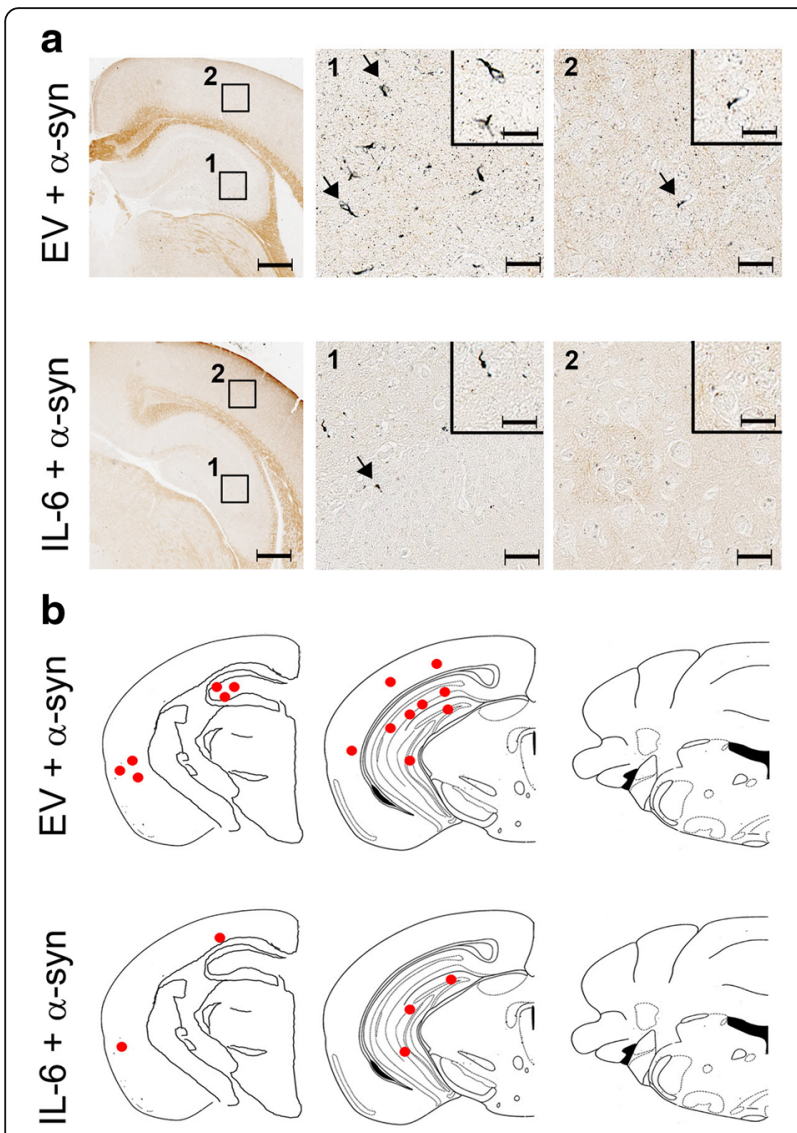

Fig. 5 Argyrophilic inclusion pathology is attenuated in IL-6 expressing mice injected in the hippocampus with aSyn fibrils. Neonatal wild type mice were injected with rAAV-EV or rAAV-IL-6 and subsequently bilaterally injected in the hippocampus with aSyn fibrils at 2 months of age. Mice were analyzed 4 months post injection with aSyn fibrils in the hippocampus. Representative images of hippocampal and cortical regions of mice stained with modified Campbell-Switzer silver staining show that mice overexpressing IL-6 have fewer silver-positive inclusions than control (EV) mice (a). Red dots show the comparative distribution of argyrophilic inclusions along rostral-caudal axis as identified by modified CampbellSwitzer silver staining (b). $n=4-5$ mice/cohort. Scale bar, $150 \mu \mathrm{m}$ (left panel) and for middle and right panels, $30 \mu \mathrm{m}$ and $15 \mu \mathrm{m}$ (inset)

exogenous $\alpha$ Syn aggregates around the time of administration, IL-6 induced gliosis was instrumental in removing the secondary pathological forms of $\alpha$ Syn at a later timepoint. The mechanism of such time-progressive reduction remains unknown but given the present understanding, it is likely that attenuation of $\alpha$ Syn pathology may occur via upregulation of phago-lysosomal function of the glial cells (reviewed in [44]). Both the autophagy-lysosomal pathway and the ubiquitin proteasome system have been shown to play crucial roles in $\alpha$ Syn clearance [45]. However, there may well be additional clearance mechanisms underlying the reduction in $\alpha$ Syn pathology observed in our study. Our data thus provides a second and unique instance where manipulating the immune system provides a beneficial response in a model of exogenous fibril-induced $\alpha$ Syn pathology. There are some caveats to such immune manipulations. Given that microarray expression data suggest that aging itself skews the human brain towards a pro-inflammatory state, it is interesting to consider how those age-induced alterations might modify the spread of neurodegenerative pathology in humans [46]. In particular, special cognizance ought to be placed on harnessing the beneficial nature of innate immune function visa-vis the potentially harmful outcomes of a chronic response.

Our present data as well as earlier reports show that CNS injection of exogenous $\alpha$ Syn aggregates leads to focal gliosis, especially discernible along the needle track [7]. Exogenous $\alpha$ Syn aggregates may cause glial dysfunction followed by intracellular proteostasis resembling neuropathological changes in synucleinopathies [7, 9]. On the other hand, astroglial activation may provide trophic support to the CNS in rodent models of PD and therefore may have beneficial neuroprotective effects overall [47, 48]. A major function of glial cells is to scavenge debris [49] and it is possible that facilitating clearance of extracellular $\alpha$ Syn may attenuate inter-neuronal transfer of $\alpha$ Syn and support normal homeostasis. Interestingly, $\alpha$ Syn is thought to be taken up by astrocytes around axon terminals in brains of PD patients [50], which was demonstrated in cell culture using exogenous $\alpha$ Syn [16]. Both astrocytes and microglia can internalize and degrade extracellular and cell-derived $\alpha$ Syn $[11,17,29,30,51,52]$. Two microglial receptors, TLR2 and TLR4, have been identified as possible endogenous receptors responsible for $\alpha$ Syn internalization; indeed, TLR4 ablation reduces $\alpha$ Syn clearance and exacerbates neurodegeneration [30]. Therefore, such astrocytic and microglial scavenging and clearance mechanisms hold promise in preventing the spread of $\alpha$ Syn pathology during inter-cellular transfer of $\alpha$ Syn seeds.

Although the general dogma in many neurodegenerative disorders is that inflammatory stimuli might promote disease [53], data in preclinical models of Alzheimer's disease demonstrate that activating the immune system can attenuate the underlying proteinopathy [33, 54-57]. We and others have demonstrated that at least early in the disease process, inflammatory activation in the CNS can have positive disease modifying effects in mouse models of Alzheimer's disease [33, 54, 58, 59]; similarly, in this study, we demonstrate that at least in an acute scenario, IL-6 induced innate immune activation can have a protective outcome in wild type mice 


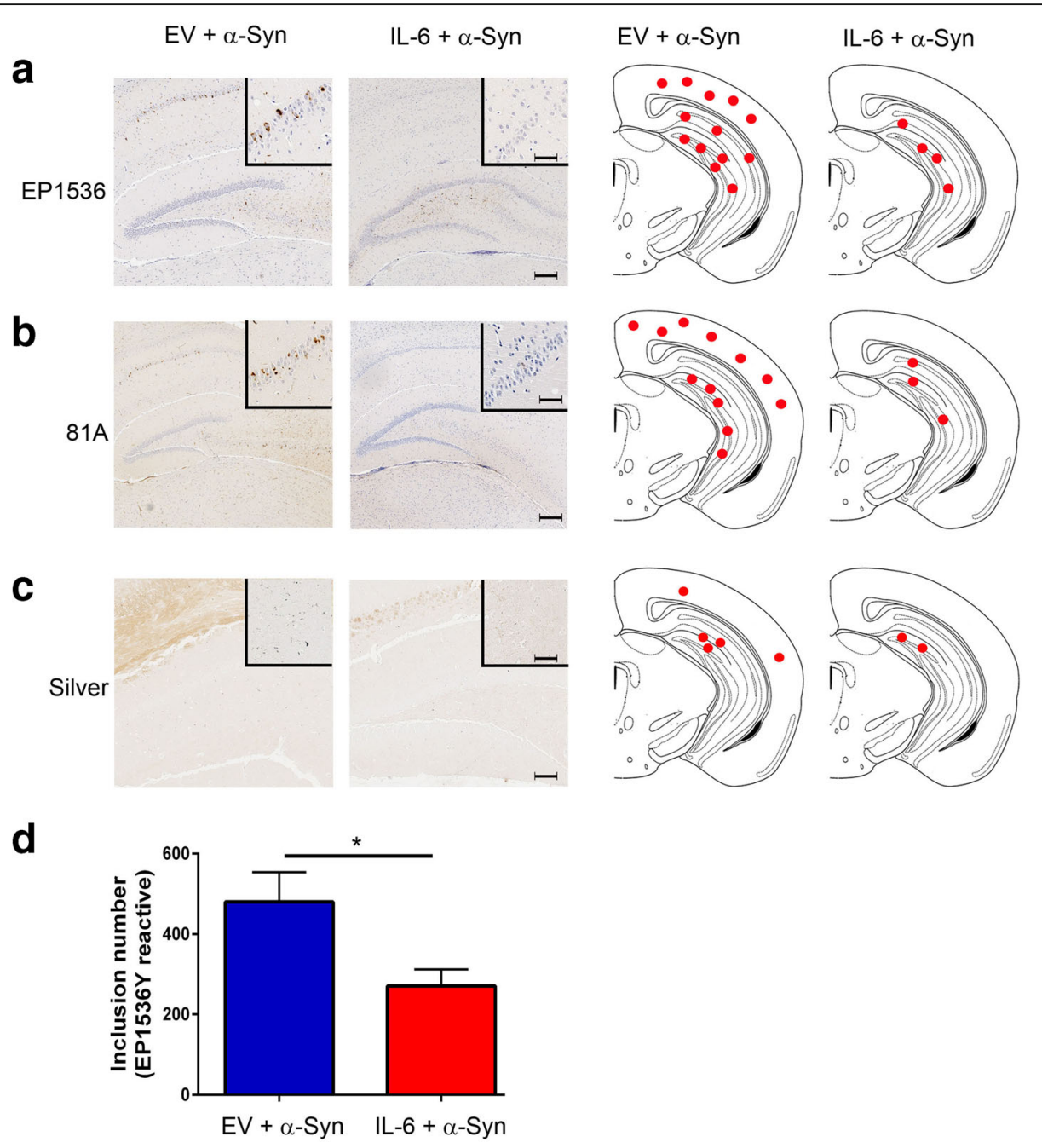

Fig. 6 Reduced aSyn pathology in IL-6 expressing mice at 2 months following intra-hippocampal injection of aSyn fibrils. Neonatal wild type mice were injected with rAAV-EV or rAAV-IL-6 and subsequently bilaterally injected in the hippocampus with aSyn fibrils at 2 months of age. pSer129 aSyn immunoreactive pathology was assessed in wild type mice 2 months post intra-hippocampal aSyn challenge. Immunolabeling with EP1536Y and 81A antibodies demonstrate reduced pathological aSyn levels in IL-6 mouse brains (a-b). Argyrophilic inclusions were also reduced in IL-6 cohort compared to the EV cohort (c). Accompanying panels on the right display the comparative distribution of pSer129 immunoreactive aSyn pathology on a representative brain map. The number of aSyn inclusions were counted in EP1536Y stained sections (whole brain) of IL-6 and EV cohorts injected with aSyn aggregates (d). ${ }^{*} p<0.05 . n=4-5$ mice/cohort. Scale bar, $300 \mu \mathrm{m}$ and $80 \mu \mathrm{m}$ (inset)

following exogenous $\alpha$ Syn challenge. To our knowledge the current data presented here is the first to show that an inflammatory interventional strategy may also work in a mouse model of seeded synucleinopathy. However, in Lewy Body diseases, the role of individual cytokines still remains to be elucidated (reviewed in [60]). Different inflammatory cytokines have been shown to be correlated with the disease process in mouse models of nigro-striatal degeneration as well as in Parkinsonian patients. Both IFN- $\gamma$ and TNF $\alpha$ have been shown to be associated with neurodegeneration in $\mathrm{PD}$ mouse models [61-63] while the role of other cytokines, such as IL-6 and IL-4 that are upregulated in PD patients [64], have not been studied before in mouse models of synucleinopathies. In particular, whether any of these latter cytokine signaling pathways can modify induction and progression of $\alpha$-synucleinopathy and therefore have translatable disease modifying outcomes is of paramount interest in therapeutics against synucleinopathies.

\section{Conclusion}

Here, we show that inflammatory priming of the CNS using IL-6 attenuates $\alpha$ Syn inclusion pathology in wild type mice. Our data adds novel insights into harnessing innate immunity as disease modifying therapies in synucleinopathies and further identifies potential immune pathways for therapeutic intervention in these diseases. 


\section{Additional files}

Additional file 1: Figure S1. Depiction of IL-6 staining in AAV injected mice. Mice were injected at neonatal day PO with rAAV-IL-6 and analyzed at 1.5 months of age. Representative whole brain images of naïve and ILexpressing mouse brain sections stained with IL-6 are presented. Magnified images from selected areas of the brain (numbered) are presented in the bottom panels. Scale bar, $600 \mu \mathrm{m}$ (top) and $15 \mu \mathrm{m}$ (bottom panels). (185 kb)

Additional file 2: Figure S2. Depiction of inflammatory activation in IL6 expressing mice injected with aSyn fibrils. Mice were injected at neonatal day PO with rAAV-IL-6 or rAAV-EV and subsequently injected in the hippocampus with aSyn at 2 months of age. Mice were analyzed 4 months post injection with aSyn fibrils in the hippocampus. Whole brain images of Empty vector (EV) and IL-6 expressing mouse brain sections that were injected with aSyn fibrils or PBS in the hippocampus are shown. Representative images stained with GFAP, Iba-1 and cd11b. These images correspond to the high power magnified images shown in Fig. 2b-d. Scale bar, $600 \mu$ m. (4.74 MB)

Additional file 3: Figure S3. MHCII staining in IL-6 expressing mice injected with aSyn fibrils or PBS. Mice were injected at neonatal day PO with rAAV-IL-6 or rAAV-EV and subsequently injected in the hippocampus with aSyn at 2 months of age. Mice were analyzed 4 months post injection with aSyn fibrils in the hippocampus. Representative sections stained with MHCll antibody show that CNS expression of IL-6 alone as well as injection of aSyn fibrils leads to MHCII immunoreactivity around the ventricles. Other regions of the brain, including the hippocampus shown here, do not show any detectable MHCII immunostaining. Scale bar, $80 \mu \mathrm{m}$. (2.73 MB)

Additional file 4: Figure S4. IL-6 expression by itself does not alter p62 levels. Mice were injected at neonatal day PO with rAAV-IL-6 or rAAV-EV and subsequently injected in the hippocampus with aSyn at 2 months of age. Mice were analyzed 4 months post injection with aSyn fibrils in the hippocampus. Representative sections stained with anti-p62 antibody shows that CNS expression of IL- 6 by itself does not produce any overt changes in p62 expression. Scale bar, 80 m. (1.49 MB)

Additional file 5: Figure S5. Astrocytosis and microgliosis in IL-6 expressing mice injected with aSyn. Mice were injected at neonatal day P0 with rAAV-IL-6 or rAAV-EV and subsequently injected in the hippocampus with aSyn at 2 months of age. Mice were analyzed 2 months post hippocampal injection. Presence of IL-6 increases both GFAP and Iba-1 immunoreactivity (A-B) compared to EV cohort. Red dots depicting distribution of glial immunoreactivity in and around the aSyn injection site are presented on the right hand panel in a brain schematic. $n=5$ mice/cohort. Scale bar, $150 \mu \mathrm{m}$ and $40 \mu \mathrm{m}$ (inset). (1.18 MB)

\section{Abbreviations}

CNS: Central nervous system; DAMP: Damage associated molecular patterns; DLB: Dementia with Lewy bodies; EV: Empty AAV vector containing no expression cassette; GFAP: Glial fibrillary acidic protein; Iba-1: Ionized calciumbinding adapter molecule 1; IL-6: Interleukin-6; MSA: Multiple system atrophy; PBS: Phosphate buffered saline; PD: Parkinson's disease; rAAV1: Recombinant adeno associated virus capsid 1; aSyn: a-synuclein

\section{Acknowledgements}

Not Applicable.

\section{Funding}

This work was supported by grants from the National Parkinson Foundation (NPF-UN203) and NIH/NINDS (NS089622).

\section{Availability of data and materials}

The datasets supporting the conclusions of this article are included within the article and Additional files 1, 2, 3, 4 and 5 .

\section{Authors' contributions}

$P C$ and $B G$ conceived and coordinated the study and wrote the manuscript; PC performed all mouse injections; MMB performed mouse euthanasia and brain harvesting; EK performed all aspects of tissue processing, immunohistochemistry and drafted images for publication; TEG provided overall support and participated in data interpretation. All authors read and approved the final manuscript.

\section{Authors' information \\ MMTB is currently at the Mayo Clinic, Jacksonville, FL, USA.}

\section{Competing interests}

PC and TEG hold a patent on IL-6 as a method to suppress amyloid deposition. Other authors declare no conflict of interest.

\section{Consent for publication}

Not Applicable.

\section{Ethics approval}

All animal experiments were carried out in accordance with the University of Florida IACUC for the care and use of laboratory animals.

\section{Author details}

'Department of Neuroscience, University of Florida, Gainesville, Florida 32610, USA. ${ }^{2}$ Center for Translational Research in Neurodegenerative Disease, University of Florida, Gainesville, Florida 32610, USA. ${ }^{3}$ McKnight Brain Institute, University of Florida, 1275 Center Drive, PO Box 100159, Gainesville, Florida 32610, USA. ${ }^{4}$ Present Address: Department of Neuroscience, Mayo Clinic, Jacksonville, FL 32224, USA.

Received: 10 September 2016 Accepted: 6 December 2016

Published online: 03 January 2017

\section{References}

1. Barker RA, Williams-Gray CH. Review: The spectrum of clinical features seen with alpha synuclein pathology. Neuropathol Appl Neurobiol. 2016;42(1):6-19.

2. Goedert M. Alpha-synuclein and neurodegenerative diseases. Nat Rev Neurosci. 2001;2(7):492-501.

3. Kim WS, Kagedal K, Halliday GM. Alpha-synuclein biology in Lewy body diseases. Alzheimers Res Ther. 2014;6(5):73.

4. Uchihara T, Giasson BI. Propagation of alpha-synuclein pathology: hypotheses, discoveries, and yet unresolved questions from experimental and human brain studies. Acta Neuropathol. 2016;131(1):49-73.

5. Luk KC, Song C, O'Brien P, Stieber A, Branch JR, Brunden KR, Trojanowski JQ, Lee VM. Exogenous alpha-synuclein fibrils seed the formation of Lewy body-like intracellular inclusions in cultured cells. Proc Natl Acad Sci U S A. 2009;106(47):20051-6.

6. Sacino AN, Brooks M, McGarvey NH, McKinney AB, Thomas MA, Levites $Y$, Ran Y, Golde TE, Giasson BI. Induction of CNS alpha-synuclein pathology by fibrillar and non-amyloidogenic recombinant alpha-synuclein. Acta Neuropathol Commun. 2013;1(1):38

7. Sacino AN, Brooks M, McKinney AB, Thomas MA, Shaw G, Golde TE, Giasson $\mathrm{BI}$. Brain injection of alpha-synuclein induces multiple proteinopathies, gliosis, and a neuronal injury marker. J Neurosci. 2014;34(37):12368-78.

8. Masuda-Suzukake M, Nonaka T, Hosokawa M, Kubo M, Shimozawa A, Akiyama H, Hasegawa M. Pathological alpha-synuclein propagates through neural networks. Acta Neuropathol Commun. 2014;2:88.

9. Luk KC, Kehm VM, Zhang B, O'Brien P, Trojanowski JQ, Lee VM. Intracerebral inoculation of pathological alpha-synuclein initiates a rapidly progressive neurodegenerative alpha-synucleinopathy in mice. J Exp Med. 2012;209(5): 975-86.

10. Volpicelli-Daley LA, Luk KC, Patel TP, Tanik SA, Riddle DM, Stieber A, Meaney DF, Trojanowski JQ, Lee VM. Exogenous alpha-synuclein fibrils induce Lewy body pathology leading to synaptic dysfunction and neuron death. Neuron. 2011;72(1):57-71.

11. Sacino AN, Thomas MA, Ceballos-Diaz C, Cruz PE, Rosario AM, Lewis J, Giasson BI, Golde TE. Conformational templating of alpha-synuclein aggregates in neuronal-glial cultures. Mol Neurodegener. 2013;8:17.

12. Sacino AN, Brooks M, Thomas MA, McKinney AB, Lee S, Regenhardt RW McGarvey NH, Ayers Jl, Notterpek L, Borchelt DR, et al. Intramuscular injection of alpha-synuclein induces CNS alpha-synuclein pathology and a rapid-onset motor phenotype in transgenic mice. Proc Natl Acad Sci U S A. 2014;111(29):10732-7. 
13. Sacino AN, Brooks M, Thomas MA, McKinney AB, McGarvey NH, Rutherford NJ, Ceballos-Diaz C, Robertson J, Golde TE, Giasson Bl. Amyloidogenic alphasynuclein seeds do not invariably induce rapid, widespread pathology in mice. Acta Neuropathol. 2014;127(5):645-65

14. Luk KC, Kehm V, Carroll J, Zhang B, O'Brien P, Trojanowski JQ, Lee VM. Pathological alpha-synuclein transmission initiates Parkinson-like neurodegeneration in nontransgenic mice. Science. 2012;338(6109):949-53.

15. Masuda-Suzukake M, Nonaka T, Hosokawa M, Oikawa T, Arai T, Akiyama H, Mann DM, Hasegawa M. Prion-like spreading of pathological alphasynuclein in brain. Brain. 2013;136(Pt 4):1128-38.

16. Lee HJ, Suk JE, Patrick C, Bae EJ, Cho JH, Rho S, Hwang D, Masliah E, Lee SJ. Direct transfer of alpha-synuclein from neuron to astroglia causes inflammatory responses in synucleinopathies. J Biol Chem. 2010;285(12): 9262-72.

17. Lee HJ, Suk JE, Bae EJ, Lee JH, Paik SR, Lee SJ. Assembly-dependent endocytosis and clearance of extracellular alpha-synuclein. Int J Biochem Cell Biol. 2008;40(9):1835-49.

18. Oh SH, Kim HN, Park HJ, Shin JY, Bae EJ, Sunwoo MK, Lee SJ, Lee PH. Mesenchymal stem cells inhibit transmission of alpha-synuclein by modulating clathrin-mediated endocytosis in a parkinsonian model. Cell Rep. 2016:14(4):835-49.

19. Golde TE, Borchelt DR, Giasson BI, Lewis J. Thinking laterally about neurodegenerative proteinopathies. J Clin Invest. 2013;123(5):1847-55.

20. Brundin P, Li JY, Holton JL, Lindvall O, Revesz T. Research in motion: the enigma of Parkinson's disease pathology spread. Nat Rev Neurosci. 2008;9(10):741-5.

21. Sacino AN, Ayers Jl, Brooks MM, Chakrabarty P, Hudson 3rd VJ, Howard JK, Golde TE, Giasson BI, Borchelt DR. Non-prion-type transmission in A53T alphasynuclein transgenic mice: a normal component of spinal homogenates from naive non-transgenic mice induces robust alpha-synuclein pathology. Acta Neuropathol. 2016;131(1):151-4.

22. Croisier E, Graeber MB. Glial degeneration and reactive gliosis in alphasynucleinopathies: the emerging concept of primary gliodegeneration. Acta Neuropathol. 2006;112(5):517-30.

23. Fellner $L$, Jellinger KA, Wenning GK, Stefanova N. Glial dysfunction in the pathogenesis of alpha-synucleinopathies: emerging concepts. Acta Neuropathol. 2011;121(6):675-93.

24. Jellinger KA, Lantos PL. Papp-Lantos inclusions and the pathogenesis of multiple system atrophy: an update. Acta Neuropathol. 2010;119(6):657-67.

25. Hishikawa N, Hashizume Y, Yoshida M, Niwa J, Tanaka F, Sobue G. Tuftshaped astrocytes in Lewy body disease. Acta Neuropathol. 2005;109(4): 373-80.

26. Gu XL, Long CX, Sun L, Xie C, Lin X, Cai H. Astrocytic expression of Parkinson's disease-related A53T alpha-synuclein causes neurodegeneration in mice. Mol Brain. 2010;3:12.

27. Ubhi K, Rockenstein E, Mante M, Inglis C, Adame A, Patrick C, Whitney K, Masliah E. Neurodegeneration in a transgenic mouse model of multiple system atrophy is associated with altered expression of oligodendroglialderived neurotrophic factors. J Neurosci. 2010;30(18):6236-46.

28. Yazawa I, Giasson BI, Sasaki R, Zhang B, Joyce S, Uryu K, Trojanowski $J Q$, Lee VM. Mouse model of multiple system atrophy alpha-synuclein expression in oligodendrocytes causes glial and neuronal degeneration. Neuron. 2005:45(6):847-59.

29. Kim C, Ho DH, Suk JE, You S, Michael S, Kang J, Joong Lee S, Masliah E, Hwang D, Lee HJ, et al. Neuron-released oligomeric alpha-synuclein is an endogenous agonist of TLR2 for paracrine activation of microglia. Nat Commun. 2013:4:1562

30. Stefanova N, Fellner L, Reindl M, Masliah E, Poewe W, Wenning GK. Toll-like receptor 4 promotes alpha-synuclein clearance and survival of nigral dopaminergic neurons. Am J Pathol. 2011;179(2):954-63.

31. Zhang W, Wang T, Pei Z, Miller DS, Wu X, Block ML, Wilson B, Zhang W, Zhou Y, Hong JS, et al. Aggregated alpha-synuclein activates microglia: process leading to disease progression in Parkinson's disease. FASEB J. 2005;19(6):533-42.

32. Kishimoto T. IL-6: from its discovery to clinical applications. Int Immunol 2010;22(5):347-52

33. Chakrabarty P, Jansen-West $K$, Beccard A, Ceballos-Diaz C, Levites $Y$, Verbeeck C, Zubair AC, Dickson D, Golde TE, Das P. Massive gliosis induced by interleukin-6 suppresses Abeta deposition in vivo: evidence against inflammation as a driving force for amyloid deposition. FASEB J. 2010;24(2): 548-59.
34. Waxman EA, Giasson BI. Induction of intracellular tau aggregation is promoted by alpha-synuclein seeds and provides novel insights into the hyperphosphorylation of tau. J Neurosci. 2011;31(21):7604-18.

35. Waxman EA, Giasson BI. A novel, high-efficiency cellular model of fibrillar alpha-synuclein inclusions and the examination of mutations that inhibit amyloid formation. J Neurochem. 2010;113(2):374-88.

36. Waxman EA, Giasson BI. Specificity and regulation of casein kinase-mediated phosphorylation of alpha-synuclein. J Neuropathol Exp Neurol. 2008;67(5):402-16.

37. Switzer 3rd RC. Application of silver degeneration stains for neurotoxicity testing. Toxicol Pathol. 2000;28(1):70-83.

38. Kuusisto E, Parkkinen L, Alafuzoff I. Morphogenesis of Lewy bodies: dissimilar incorporation of alpha-synuclein, ubiquitin, and p62. J Neuropathol Exp Neurol. 2003:62(12):1241-53.

39. Zatloukal K, Stumptner C, Fuchsbichler A, Heid H, Schnoelzer M, Kenner L, Kleinert R, Prinz M, Aguzzi A, Denk H. p62 Is a common component of cytoplasmic inclusions in protein aggregation diseases. Am J Pathol. 2002; 160(1):255-63.

40. Uchihara T, Nakamura A, Mochizuki Y, Hayashi M, Orimo S, Isozaki E, Mizutani T. Silver stainings distinguish Lewy bodies and glial cytoplasmic inclusions: comparison between Gallyas-Braak and Campbell-Switzer methods. Acta Neuropathol. 2005;110(3):255-60.

41. Glass CK, Saijo K, Winner B, Marchetto MC, Gage FH. Mechanisms underlying inflammation in neurodegeneration. Cell. 2010;140(6):918-34.

42. Brundin P, Atkin G, Lamberts JT. Basic science breaks through: new therapeutic advances in Parkinson's disease. Mov Disord. 2015;30(11):1521-7.

43. Tran HT, Chung CH, Iba M, Zhang B, Trojanowski JQ, Luk KC, Lee VM. Alphasynuclein immunotherapy blocks uptake and templated propagation of misfolded alpha-synuclein and neurodegeneration. Cell Rep. 2014;7(6):2054-65.

44. Lopes Da Fonseca T, Villar-Pique A, Outeiro TF. The interplay between alpha-synuclein clearance and spreading. Biomolecules. 2015;5(2):435-71.

45. Webb JL, Ravikumar B, Atkins J, Skepper JN, Rubinsztein DC. Alpha-synuclein is degraded by both autophagy and the proteasome. J Biol Chem. 2003;278(27):25009-13.

46. Cribbs DH, Berchtold NC, Perreau V, Coleman PD, Rogers J, Tenner AJ, Cotman CW. Extensive innate immune gene activation accompanies brain aging, increasing vulnerability to cognitive decline and neurodegeneration: a microarray study. J Neuroinflammation. 2012;9:179.

47. Knott C, Stern G, Kingsbury A, Welcher AA, Wilkin GP. Elevated glial brainderived neurotrophic factor in Parkinson's diseased nigra. Parkinsonism Relat Disord. 2002:8(5):329-41.

48. Sandhu JK, Gardaneh M, Iwasiow R, Lanthier P, Gangaraju S, RibeccoLutkiewicz M, Tremblay R, Kiuchi K, Sikorska M. Astrocyte-secreted GDNF and glutathione antioxidant system protect neurons against 6OHDA cytotoxicity. Neurobiol Dis. 2009;33(3):405-14.

49. Neumann H, Kotter MR, Franklin RJ. Debris clearance by microglia: an essential link between degeneration and regeneration. Brain. 2009;132(Pt 2):288-95.

50. Braak H, Sastre M, Del Tredici K. Development of alpha-synuclein immunoreactive astrocytes in the forebrain parallels stages of intraneuronal pathology in sporadic Parkinson's disease. Acta Neuropathol. 2007:114(3): 231-41

51. Park JY, Paik SR, Jou I, Park SM. Microglial phagocytosis is enhanced by monomeric alpha-synuclein, not aggregated alpha-synuclein: implications for Parkinson's disease. Glia. 2008:56(11):1215-23.

52. Fellner L, Irschick R, Schanda K, Reindl M, Klimaschewski L, Poewe W, Wenning GK, Stefanova N. Toll-like receptor 4 is required for alpha-synuclein dependent activation of microglia and astroglia. Glia. 2013;61(3):349-60.

53. Frank-Cannon TC, Alto LT, McAlpine FE, Tansey MG. Does neuroinflammation fan the flame in neurodegenerative diseases? Mol Neurodegener. 2009:4:47

54. Shaftel SS, Kyrkanides S, Olschowka JA, Miller JN, Johnson RE, O'Banion MK. Sustained hippocampal IL-1 beta overexpression mediates chronic neuroinflammation and ameliorates Alzheimer plaque pathology. J Clin Invest. 2007;117(6):1595-604.

55. Lee DC, Rizer J, Selenica ML, Reid P, Kraft C, Johnson A, Blair L, Gordon MN, Dickey CA, Morgan D. LPS- induced inflammation exacerbates phospho-tau pathology in rTg4510 mice. J Neuroinflammation. 2010;7:56.

56. Li A, Ceballos-Diaz C, DiNunno N, Levites Y, Cruz PE, Lewis J, Golde TE, Chakrabarty P. IFN-gamma promotes tau phosphorylation without affecting mature tangles. FASEB J. 2015;29(10):4384-98.

57. Marsh SE, Abud EM, Lakatos A, Karimzadeh A, Yeung ST, Davtyan H, Fote GM, Lau L, Weinger JG, Lane TE, et al. The adaptive immune system 
restrains Alzheimer's disease pathogenesis by modulating microglial function. Proc Natl Acad Sci U S A. 2016;113(9):E1316-1325.

58. Herber DL, Mercer M, Roth LM, Symmonds K, Maloney J, Wilson N, Freeman MJ, Morgan D, Gordon MN. Microglial activation is required for Abeta clearance after intracranial injection of lipopolysaccharide in APP transgenic mice. J Neuroimmune Pharmacol. 2007;2(2):222-31.

59. Scholtzova H, Kascsak RJ, Bates KA, Boutajangout A, Kerr DJ, Meeker HC, Mehta PD, Spinner DS, Wisniewski T. Induction of toll-like receptor 9 signaling as a method for ameliorating Alzheimer's disease-related pathology. J Neurosci. 2009;29(6):1846-54.

60. Tansey MG, Goldberg MS. Neuroinflammation in Parkinson's disease: its role in neuronal death and implications for therapeutic intervention. Neurobiol Dis. 2010;37(3):510-8.

61. Barcia C, Ros CM, Annese V, Gomez A, Ros-Bernal F, Aguado-Yera D, Martinez-Pagan ME, de Pablos V, Fernandez-Villalba E, Herrero MT. IFNgamma signaling, with the synergistic contribution of TNF-alpha, mediates cell specific microglial and astroglial activation in experimental models of Parkinson's disease. Cell Death Dis. 2011;2:e142.

62. Mount MP, Lira A, Grimes D, Smith PD, Faucher S, Slack R, Anisman H, Hayley S, Park DS. Involvement of interferon-gamma in microglial-mediated loss of dopaminergic neurons. J Neurosci. 2007;27(12):3328-37.

63. Chakrabarty P, Ceballos-Diaz C, Lin WL, Beccard A, Jansen-West K, McFarland NR, Janus C, Dickson D, Das P, Golde TE. Interferon-gamma induces progressive nigrostriatal degeneration and basal ganglia calcification. Nat Neurosci. 2011;14(6):694-6.

64. Mogi M, Harada M, Narabayashi H, Inagaki H, Minami M, Nagatsu T. Interleukin (IL)-1 beta, IL-2, IL-4, IL-6 and transforming growth factor-alpha levels are elevated in ventricular cerebrospinal fluid in juvenile parkinsonism and Parkinson's disease. Neurosci Lett. 1996;211(1):13-6.

\section{Submit your next manuscript to BioMed Central and we will help you at every step:}

- We accept pre-submission inquiries

- Our selector tool helps you to find the most relevant journal

- We provide round the clock customer support

- Convenient online submission

- Thorough peer review

- Inclusion in PubMed and all major indexing services

- Maximum visibility for your research

Submit your manuscript at www.biomedcentral.com/submit 